\title{
Editorial 2020 - Obituaries
}

\author{
Imre Miklós Szilágyi ${ }^{1}$ · Alfréd Kállay-Menyhárd ${ }^{2}$ · Sophie Korda ${ }^{3}$ - György Liptay ${ }^{1}$
}

Published online: 30 January 2020

(c) Akadémiai Kiadó, Budapest, Hungary 2020

Dear Readers,

Some great researchers have passed away in recent years, who made decisive contributions to the development of thermal analysis, and who also contributed considerably to the success of the now 50-year-old Journal of Thermal Analysis and Calorimetry (JTAC). We are indebted to them to a very large extent. In this issue, we are remembering them, through the words of friends and colleagues, who were close to these outstanding scientists. Accordingly, we are publishing obituaries about Michael Ewart Brown, José Manuel Criado, John Redfern, Eugen Segal and Hans-Joachim Seifert. We are also remembering Anna Langier-Kużniarowa, about who an obituary [1] has been already published recently.

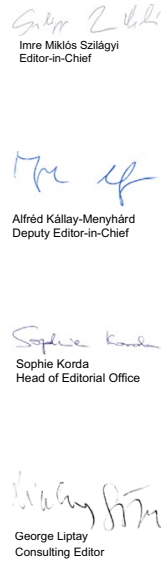

Imre Miklós Szilágyi

imre.szilagyi@mail.bme.hu

1 Department of Inorganic and Analytical Chemistry,

Budapest University of Technology and Economics, Szt.

Gellért Square 4, Budapest 1111, Hungary

2 Department of Physical Chemistry and Materials Science, Budapest University of Technology and Economics,

P.O. Box 92, Budapest 1521, Hungary

3 Akadémiai Kiadó, Budafoki út 187-189, Budapest 1117, Hungary

\section{Reference}

1. Maliszewska Anna, Niemczynow-Burchart Grażyna. In memory of Langer-Kużniar (1931-2016). Mineralogia. 2016;1-4:11-4. https://doi.org/10.1515/mipo-2017-0003.

Publisher's Note Springer Nature remains neutral with regard to jurisdictional claims in published maps and institutional affiliations. 